\title{
Geleceğimiz Olan Z Kuşağının Çalışma Hayatına Muhtemel Etkileri ${ }^{1}$
}

\author{
DOI: $10.26466 /$ opus.370345
}

\section{H. Yunus Taş* - Mehmet Demirdöğmez ${ }^{* *}-$ Mahmut Küçükoğlu***}

* Doç. Dr., Yalova Üniversitesi, İktisadi ve İdari Bilimler Fakültesi Yalova/Türkiye E-Posta: yunus.tas@yalova.edu.tr ORCID: 0000-0003-3163-9416

** Öğr. Gör., Harran Üniversitesi, Birecik Meslek Yüksek Okulu, Şanlıurfa/Türkiye E-Posta: mdemirdogmez@harran.edu.tr ORCID: $0000-0001-5104-7042$

** Yrd. Doç. Dr., Harran Üniversitesi, Şanlıurfa Meslek Yüksek Okulu, Şanlıurfa /Türkiye

E-Posta: mkucukoglu@harran.edu.trＯRCID: 0000-0002-8286-6929

\section{Öz}

Değişimin hızlı olduğu dünyamızda aile yapıları, toplumsal değerler, çalışma hayatı ve kuşaklar arasındaki farklılıklar da hızla değişmektedir. İnsanlık tarihi boyunca, her nesil önceki nesile göre daha fazla bilgi ve beceriye sahip olduğu için hızl ilerleme kaydetmiş ve daha iyi şartlarda yaşamıştır. Insanın yaradılışı gereği çıkarları, amaçları, duyguları ve ihtiyaçları zaman ve şartlara göre hızla değiştiği için nesiller arası farklılıklar da buna paralel olarak değgişikliğge uğramıştır. Insanın yapısı gereği amaçları, duyguları ve ihtiyaçları her dönemde hızla değiştiği için kuşaklar arası farklılıklar da buna paralel olarak değişmiştir. Bu değişimi dijital teknolojilerin her alanda hayatın vazgeçilmez bir parçası haline geldiği günümüz şartlarında bu teknolojileri faal ve karışık bir biçimde kullanan kuşak olan ve "Z Kuşağı" veya "Z Nesli" olarak adlandırılan kuşakta görmekteyiz. Bu gelişmenin sonucu olarak, bu dijital ortamda doğan ve bu teknolojiden etkilenerek büyüyen çocuklarm da kendilerinden önceki kuşaklardan farklılaşması doğaldır. Bu çalışma; Literatür taramaları ve gerek çevremizdeki Z kuşağındaki gençler gerekse yine bu kuşakta bulunan üniversitedeki öğrencilerimizden gözlem yoluyla yapılan bazı tespitlerle tamamlanmıştır. Bu çalışmanın amacı $\mathrm{Z}$ kuşağı denen ve bazı kaynaklarda 1995 yılından sonra doğanlar, bazılarında ise 2000 yılı ve sonrası kuşak olarak nitelendirilen nesil özelliklerini belirlemekle beraber, istihdamları konusunda işletmelerin, kurumları, firmaların vb. kuruluşların takınacakları ve takınmaları gereken tavırların ve işletme politikaların ortaya koymaktır.

Anahtar Kelimeler : Z kuşağı, Y kuşă̆ ${ }^{\prime}$, Genç Beyinler, İstihdam, İnternet

\footnotetext{
${ }^{1}$ Bu Makale işKUR, 2017 Uluslararası Istihdam Ve Kariyer Kongresinde Sunumu Yapılan, Tebliğimiz Esas Alınarak Hazırlanmıştır.
} 


\title{
Possible Effects of Future Architects' Z Generation on Business Life
}

\author{
DOI: $10.26466 /$ opus.370345
}

\begin{abstract}
In our world where change is fast, the differences between family structures, social values, working lives and generations are changing rapidly. Throughout the history of mankind, each generation has made more progress and better conditions than ever before because it has more knowledge and skill than the previous generation. Because the interests of the human being are in their interests, their aims, feelings and needs change rapidly according to time and circumstances, the differences between generations have also changed accordingly. Since the aims, emotions and needs of man's structure have changed rapidly in every period, the intergenerational differences have also changed accordingly. In this day and age where digital technology has become an indispensable part of life in every field, we see this change in the generation called ' $Z$ Generation', a generation that uses these technologies in an active and complicated way. As a result of this development, it is natural that the children born in this digital environment and growing by being influenced by this technology are also differentiated from their predecessors. This work; Literature scans and young people in the circle $Z$ are also completed by observing the students from the university in this generation. The purpose of this study is to determine the characteristics of the generation called $Z$ generation, which are defined as generation after 1995 and some generation after 2000, in some sources, enterprises, institutions, firms etc. in terms of employment. is to set out the attitudes and operating policies of the organizations to attach and attach.
\end{abstract}

Keywords: Z generation, Generation Y, Young Brains, Employment, Internet 


\section{Giriş}

21. Yüzyılın yönetici çalışan ve üreten kesimini oluşturacak imar ve inşasinda önemli bir yer tutacak olan $Z$ kuşağ1 olan günümüzün çocuk ve gençlerini gelecekte nasıl görmek isteriz. Ya da çalışma ve iş hayatına yönelik olarak onların beklentilerini karşılamaya ve onları anlamaya hazırmıyız. Çalışma hayatından beklentileri nelerdir. $\mathrm{Bu}$ ve benzeri sorulara cevap aramak ve sağlıklı bir dünyada sağlıklı kararlar verebilmek için $Z$ kuşağı Y kuşağını Y ise X kuşakları karşılıklı olarak birbirlerini anlamak ve dinlemek dorumundadır.

$\mathrm{Z}$ kuşağını diğer kuşaklardan ayıran en önemli özelliği dijital yüksek teknolojinin yaygın olarak kullanıldığı bir zaman diliminde dünyaya gelmeleridir. Dijital ve yüksek teknolojinin günlük hayatımıza yön verdiği sosyal medyanın hayatımızın her alanını etkilediği bir dönemde bu teknolojinin faydalı bir şekilde kullanmanın yollarını öğrenme ve öğretme görevi önem kazanmaktadır. Bu görevi kim ya da kimlerin devralacağı ve nasıl bir program dâhilinde kullanılacağ 1 çok önemlidir.

Bu görev ebetteki ülkenin yönetim ve eğitim kademelerinde yer alan yöneticiler, eğitimciler ve akademisyenler tarafından yapılmalıdır.

Bilgisayarı ve dijital teknolojiyi çok yoğun kullanan Z kuşağı metinleri konuşmaya, bilgisayarı okumaya tercih etmektedirler. Bu kuşağın bireyleri dışarıda çok zaman harcamazlar, çevrimiçi iletişim kurarlar, bilgisayarsız ve ya cep telefonsuz bir hayatı hayal bile edemezler. Teknolojisiz bir yaşamdan haberdar değildirler. Ekonomik depresyon yaşayarak büyüyen bu kuşak büyük bir ekonomik baskı altında iş hayatına adım atacaktır. İş dünyası da, Z kuşağını, iyi eğitimli ve kendini sürekli geliştiren bir nesil olarak değerlendirmektedir.

Detaylarda kaybolmadıkları ve nokta atışı yapabildikleri için şirketlerin verimli çalışması ve başarılı olmasın da büyük rol oynayabiliyorlar. Z kuşağının sağlayacağı bu tür faydalarla öne çıktığını söyleyebiliriz. Ancak aidiyet duygularının az ve çabuk vazgeçme huylarının olması da işletmelerin standart sistemlerinde bu kişileri bünyelerinde tutmalarının zorluğunu da belirtmek gerekir. Z kuşağı, takım çalışması yerine daha çok bireysel hareket etmeyi seven ve kendilerini ifade edebilecekleri alanlar oluşturabilen kuşak olarak kabul ediliyor. 
Bu kuşak için para kazanmanın yanında, iş tatmini de önemli. Bilginin ve zamanın hızına anında adapte olabilme özelliği taşırlar ve bu bireyler, çalışırken eğlenmenin ve sürekli öğrenmenin peşindedirler. Özellikle teknolojinin büyük etkisiyle yeteneklerini hızla geliştirebilme imkânına ve örgütlerin geleceklerini belirleyecek çoğunluğa sahip olmalarından dolayı, bu kuşak, işletmelerin ihtiyaç duyduğu en önemli varlık haline gelmiştir.

İşletmelerdeki pozisyonlarla uyum sağlandığında, örgütler açısından fark oluşturacak olan bir kuşak, Z kuşağı. Sınırsız kariyer anlayışı ve zayıf örgütsel bağlllık gibi farklılıklarından dolayı bu bireyleri işletmeye çekmek, onlara gereken değeri vermek, onları kariyer açısından geliştirmek ve işletmede tutabilmek için örgütler artık geleneksel insan kaynakları uygulamalarından yetenek yönetimi anlayışına geçmelidirler.

\section{Farklı Kuşaklar ve Kuşak Farklılıkları}

Toplum hayatı açısından ilerlemek ve mesafe kat edebilmek için bir kuşağın kendinden sonraki kuşağa aktaracağı tecrübe ve birikimlerle mümkün olacağı bilinen temel gerçeklerdendir, kuşakların değişimlerinin belirli bir süreç içerisinde hareket eden kuvvetler olduğu belirtilmektedir (Comte, 1974: 635-641). Daha sonraki yıllarda araştırmacı Karl Mannheim (Mannheim,1998), kuşaklar konusunda kapsamlı ve sistematik bir araştırma yapmıştır. Mannheim çalışmasında, kuşakları, ortak alışkanlıklara ve ortak kültürlere sahip olan ve bu değerleri paylaşan insanlar topluluğu olarak tanımlamıştır. Jean-Claude Lagree (Lagree ,1991: 7) kuşak kavramını, aynı tarihsel dönemde yaşamış, aynı olaylardan etkilenmiş, aynı sosyal kimliğe sahip topluluklar olarak tanımlamıştır.

Türk dil kurumu terimler sözlügünde, kuşak veya nesil kelimelerini Aşağı yukarı aynı yıllarda doğmuş olup aynı çağın koşullarını, dolayısıyla birbirine benzer sıkıntıları, yazgıları yaşamış, benzer ödevlerle yükümlü olmuş kişilerin topluluğu olarak tanımlanmaktadır (www.tdkterim.gov.tr).

Sosyolojik tanımlar incelendiğinde, kuşaklar, belli tarihlerde doğmuş, sosyalleşme sürecinde ortak sosyal, politik, ekonomik vb. olaylardan etki- 
lenmiş, koşullar gereği benzer sorumluluklar yüklenmiş oldukları için ortak değer, inanç, beklenti ve davranışlara sahip gruplar olarak tanımlanabilir.

Kuşakları sadece doğdukları zaman açısından sınıflandırıp değerlendirmek doğru değildir. Aynı zamanda kuşaklar topluluğunu oluşturan bireylerin duyguları, düşünceleri ve deneyimlerinin tanımlanması da, gereklidir. Her kuşağın hayatı algılama şekilleri ve farklı iletişim tarzlarıyla "mevcut yaşam ve çalışma alışkanlıklarının dışında" kendine özgü karakteristik özellikleri, değer yargıları ve tutumları, güçlü ve zayıf yönleri vardır. Bu kuşaklar doğdukları yıllara göre;1965-1979 arasına "X Kuşağı", 1980-1999 arasına "Y Kuşağı" ve 2000-2021 arasında doğanlara ise "Z Kuşağı" olarak tanımlanmaktadırlar. (www.humanica.com.tr)

Kuşak teorisi X kuşağını; 1960-70'li yıllarda doğmuş olan, kariyer yapmayı önemseyen, eğitim almış, kitap okumak yerine film izlemeyi tercih eden, duygusal, bakımlı, değişime açık, meslekî açıdan başarıya odaklanmış performanstaki kişiler, farklı coğrafyalarda benzer özellikleri olan bireyler olarak tanımlamış, idealist, kanaatkâr ve sadık bir nesil olarak resmedilmiştir (Senbir, 2004: 24) . X nesli kurallara uyan, aidiyet özelliği güçlü, otoriteye saygı duyan, sadakati ve çalışkanlığı ile öne çıkan bir kuşak olarak tanımlanan (www.mostar.com.tr) bu nesil, bir çok buluş ve icatlara şahitlik etmiştir. Merdaneli çamaşır makinesi, transistörlü radyo, kasetçalar ve pikapla Dünyaya gözlerini açan X nesli sakinleri pek çok dönüşüm yaşamıştır. Teknolojik açıdan, bilgisayar sistemlerine ve buna bağlı olarak değişen iş yapma şekillerine adapte olmaya çalışmışlardır(www.hurriyet.com.tr).Y kuşağı; 1980-1999 yılları arasında doğan, teknolojik yenilikleri bilen, bilgisayar ve atari oyunlarıyla büyümüş, ergenlik döneminde cep telefonlarıyla tanışmış, sosyal yönü gelişmiş, iş ortamında ve mesai saatlerinde esnekliği benimsemiş, kariyerden çok kendini ifade etmeyi önemseyen, karar alma aşamasında aktif rol üstlenen jenerasyondur (Howe ve Strauss, 1992). Y nesli, kuşaklar arası farklılığın en çok hissedildiği nesil özelliği taşırlar. Çünkü onlar bağımsız olmayı seviyorlar, özgürlüklerine düşkünler ve iş yaşamlarında da farklılar. Belirlenen mesai saatleri arasında çalışmayı sevmiyorlar. Bu yüzden, iş saatinden ziyade işe odaklanmaları gerekiyor. Bu durumda onları işin bir parçası haline getirmek önemlidir. $X$ nesline göre $Y$ neslinin örgütsel bağlılıkları azdır ve 
çok fazla iş değiştirdikleri de söyleniyor.( danisman-muratdanisman.blogspot.com X ve $Y$ kuşağı teorisi özellikle internetin yaygınlaşması, cep telefonu, tablet gibi ürünlerin hayatımızın vazgeçilmezi olmasıyla birlikte Hammill (Hammill, 2005) tarafından yetersiz görülmüş ve Z kuşağ1 olgusuyla geliştirilmiştir.

Z kuşağı 2000 ve sonrasında doğmuş kişileri ifade etmektedir. Bilgiye ulaşma kapasiteleri, teknoloji sayesinde, çok daha yüksektir. Erken yaşta eğitim almaya başlayan Z kuşağı daha hızlı zihinsel gelişim göstermektedir. X ve Y kuşaklarına göre bireycilikleri daha kuvvetlidir. Sosyalleşme yollarının en belirgin olanı sosyal medyadır. Dijital çağın çocukları olara kabul edilen $Z$ kuşağının aynı anda birçok işi yapabilme yeteneklerinin olduğu bilinmektedir. Z kuşağı, giyilebilir, taşınabilir vb. teknoloji ürünlerini günlük hayatının vazgeçilmez bir parçası hâline getirmiştir(Senbir 2004: 27-28; Williams, 2010: 12) Z kuşağı, internet ve mobil teknolojileri kullanmayı seviyor. Oyuncak yerine ipad'lerle oynuyorlar ve teknoloji ile birlikte büyüyorlar. Günümüzde yaygın olan akıllı telefonlar, ipad'ler ya da tablet bilgisayarlar ile her alanda aktif durumdalar. Özellikle internet aracı̆̆ıyla sosyalleşmeyi tercih ediyorlar(www.hurriyet.com.tr).

Tablo 1: X, Y ve Z Kuşaklarının Teknoloji Kullanımları ve Beğenileri

\begin{tabular}{|l|l|l|l|}
\hline & $\begin{array}{l}\text { X Kuşağı } \\
1960-1979\end{array}$ & $\begin{array}{l}\text { Y Kuşağı } \\
\mathbf{1 9 8 0 - 1 9 9 9}\end{array}$ & $\begin{array}{l}\text { Z Kuşağı } \\
\text { 2000-2000+ }\end{array}$ \\
\hline Ikonik Teknoloji & $\begin{array}{l}\text { Video (VHS) } \\
\text { Walkmann } \\
\text { IBM PC }\end{array}$ & $\begin{array}{l}\text { DVD } \\
\text { İnternet-Email-SMS } \\
\text { Gameboy-Xbox } \\
\text { Ipod }\end{array}$ & $\begin{array}{l}\text { Google-Facebook } \\
\text { Twitter-Instagram } \\
\text { Ipad-Iphone } \\
\text { Android-PS4-Wii }\end{array}$ \\
\hline Popüler Kültür & $\begin{array}{l}\text { Yırtık kot } \\
\text { Aşırı renkler } \\
\text { Piercing }\end{array}$ & $\begin{array}{l}\text { Şapka } \\
\text { Erkek Kozmetiği } \\
\text { Havai tarz }\end{array}$ & $\begin{array}{l}\text { Dar pantolon } \\
\text { V yaka } \\
\text { Giyilebilir teknoloji }\end{array}$ \\
\hline Satın Alma \\
Motivasyonları & $\begin{array}{l}\text { Markalar arası } \\
\text { tercih } \\
\text { Uzmanlıklar }\end{array}$ & $\begin{array}{l}\text { Marka sadakati yok } \\
\text { Arkadaş referansı }\end{array}$ & $\begin{array}{l}\text { Marka takıntısı } \\
\text { Trendler }\end{array}$ \\
\hline ideal Lider Özelliği & $\begin{array}{l}\text { Yönlendirici } \\
\text { Otoriter }\end{array}$ & $\begin{array}{l}\text { Güçlendirici } \\
\text { İ̧̧irlikçi }\end{array}$ & $\begin{array}{l}\text { ilham verici } \\
\text { Eş yaratıcı }\end{array}$ \\
\hline Pazarlama yöntemi & $\begin{array}{l}\text { Doğrudan } \\
\text { pazarlama } \\
\text { Bilanço }\end{array}$ & $\begin{array}{l}\text { Viral } \\
\text { Referanslar } \\
\text { Elektronik pazarlama }\end{array}$ & $\begin{array}{l}\text { Etkileşimli kampan- } \\
\text { yalar } \\
\text { Marka ilgisi }\end{array}$ \\
\hline \multirow{2}{*}{ Eğitim Yöntemleri } & $\begin{array}{l}\text { Spontane } \\
\text { Etkileşimli } \\
\text { Rahat ortam } \\
\text { Masa- sıra }\end{array}$ & $\begin{array}{l}\text { Çoklu duyusal } \\
\text { Görsel } \\
\text { Kafe stili } \\
\text { Müzik-çoklu model }\end{array}$ & $\begin{array}{l}\text { Öğrenci odaklı } \\
\text { Kinestetik } \\
\text { Salon stili } \\
\text { Çoklu uyaran }\end{array}$ \\
\hline
\end{tabular}

Kaynak: McCrindle Research, Generations Defined: 50 Years of Change Over 5 Generations, (2012). 
Z neslini önceki kuşaklardan ayıran esaslı farklardan birisi, değişimin çok hızlı ve kırılmalar şeklinde yaşandığı bir dönemde dünyaya gelmeleri olarak gösterilir (Altuntuğ, 2012:206).

\section{Z Kuşağ1}

Türkiye'de 2000'den sonra doğanlardan oluşan kuşak aynı zamanda 'Kristal Nesil' olarak da adlandırılmaktadır. Uzmanların 'derin duygusal' sıfatıyla nitelendirdiği bu kuşak,(www.dijitalajanslar.com) İnternetin olmadığı bir dönemi hiç yaşamamış, ödev yaparken Ana Britannica sayfalarından hiç özet çıkarmamış bir nesil. Akıllı telefonlarıyla her yerden, sürekli sanal dünyaya 'connected' olan, birbirleriyle telefondan konuşmak hatta e-mail göndermek yerine sosyal medyadan emojiler, ikonlar ve görüntülerle konuşan bir jenerasyon. Sosyal olaylara, çevreye, teknolojik gelişmeye, ekonomiye, sosyal adaletsizlik ve eşitsizliğe daha duyarlılar.(ikiletisim.wordpress.com) Z kuşağı, zevklerine düşkün, teknolojiyi hızlı şekilde kavrayan, işlerini kısa sürede ve titiz biçimde yerine getiren davranışlarıyla dikkat çekmektedir. Tam anlamıyla teknoloji çağı çocukları olan Z Kuşağını Dijital yerliler olarak da tanımlayabiliriz. İnsanlık tarihinin el, göz, kulak vb. motor becerileri senkronizasyonu en yüksek nesli olan $Z$ kuşağı sonuç odaklı, tatminsiz, kararsız ve doğuştan tüketiciler. Yalnız yaşamayı tercih ediyorlar. Adaleti, barış iklimini önemsiyorlar. Z kuşağı bireylerinin, özellikle teknolojide meydana gelen ilerlemeler bireysel özelliklerinin diğer kuşaklardan ayrılmasına neden olmuştur. Bu kuşağın tarih boyunca en fazla eğitim almış kuşak olacağı tahmin ediliyor (www.humanica.com.tr).

Y Kuşağı'nın yaşadığı ekonomik zorlukları (global kriz sonrası sadece Türkiye'de değil, Amerika ve Avrupa'da yeni mezunlarda görülen yüksek orandaki işsizlik) gördüler, ders aldılar ve çalışmak konusunda daha duyarlılar. Y Kuşağı'na göre bu açıdan daha olgunlar. X Kuşağı'nın kafa yapısına daha yakınlar. Erken yaşta çalışma hayatına atılmak istiyorlar. Z Kuşağı'nın dikkat süresi Y Kuşağı'ndan daha da kısa. Y Kuşağı'nın tercih ettiği 140 karakterlik kısa metinlerin de ötesine sembollerle, emojiler ve emoticonlarla iletişim kuruyorlar. İletişimlerinde metinden çok görsellik ön planda. Örneğin, sosyal medyada sıkça gördügüumüz capsli resimler vb. 
bunların göstergesi. (ikiletisim.wordpress.com) Z kuşağındakiler için internette satışta olan her şey satın alınabilir. Tüm ihtiyaçları için e-ticareti tercih ediyorlar. Bu nedenle de alışveriş sepetleri normalin birkaç kat üzerinde.

Tablo: 2- X,Y ve Z Neslinin Özellikleri ve Değerleri

\begin{tabular}{|c|c|c|c|}
\hline Kuşaklar & X Kuşağı & Y Kuşağ́ & Z Kuşağı \\
\hline $\begin{array}{l}\text { Özellikleri } \\
\text { ve } \\
\text { Değerleri }\end{array}$ & $\begin{array}{ll}\text { - } & \text { Sadakat duyguları de- } \\
\text { ğişken } \\
\text { - } & \text { Otoriteye saygılı } \\
\text { - } & \text { Topluma duyarlı } \\
\text { - } & \text { İş motivasyonları yük- } \\
& \text { sek } \\
\text { - } & \text { Kanaatkâr } \\
- & \text { Kaygılı } \\
- & \text { Teknolojiyle ilişkisi dü- } \\
& \text { şük }\end{array}$ & $\begin{array}{l}\text { - Sadakat duyguları az } \\
\text { - Otoriteyi zor kabulle- } \\
\text { nen } \\
\text { - Bağımsızlığına düş- } \\
\text { kün } \\
\text { - Çok sık iş değiştiren } \\
\text { - } \text { Bireyci } \\
\text { - } \text { Teknolojiyle büyüyen }\end{array}$ & $\begin{array}{l}\text {-İşbirlikçi } \\
\text {-Yaratıcı } \\
\text {-Teknoloji içine } \\
\text { doğan }\end{array}$ \\
\hline
\end{tabular}

Kaynak: Deneçli, C. Ve Deneçli S. Nabza Göre Şerbet, Kuşağa Göre Etkinlik: Eğlencenin Pazarlanmasi http://www.iku.edu.tr/userfiles/file/sanattasrim/doc/Ceyda_Denecli_Sevda_De necli.doc Kuşaklar,

Z kuşağının neredeyse tamamı aktif sosyal medya kullanıcısı ve çoğunluğu alışveriş kararlarında e-ticaret sitelerinin sosyal medyadaki reklamlarının etkili olduğunu söylüyor. Her ne kadar müsrif gözükseler de para harcama yerine biriktirmeyi tercih ediyorlar. Kampanyaları yakından takip ediyorlar, firsat sitelerinin en aktif kullanıcıları durumundalar. $\mathrm{Z}$ kuşağının en belirgin özelliklerinden biri de araştırmacı olmaları. Yüzde 80'i alışveriş yapmadan önce araştırıyor, fiyat karşılaştırması yapıyor. Z Kuşağı, Markadan çok kullanılabilir olmasını, kaliteyi önemsiyor.( epnext.com) Yapılan araştırmaya göre, dijital dünyanın içine doğan ve ortamlarda büyüyen Z kuşağı, yüzde 97 oranı ile en çok YouTube' da varlık gösteriyor.

Araştırmanın en dikkat çekici sonuçlarından birisi ise dijital dünyanın $\mathrm{Z}$ nesli çocuklarının sosyal hayatına etkisi. Dijitalleşme, davranış biçimlerini değiştiriyor( www.hurriyet.com.tr). 


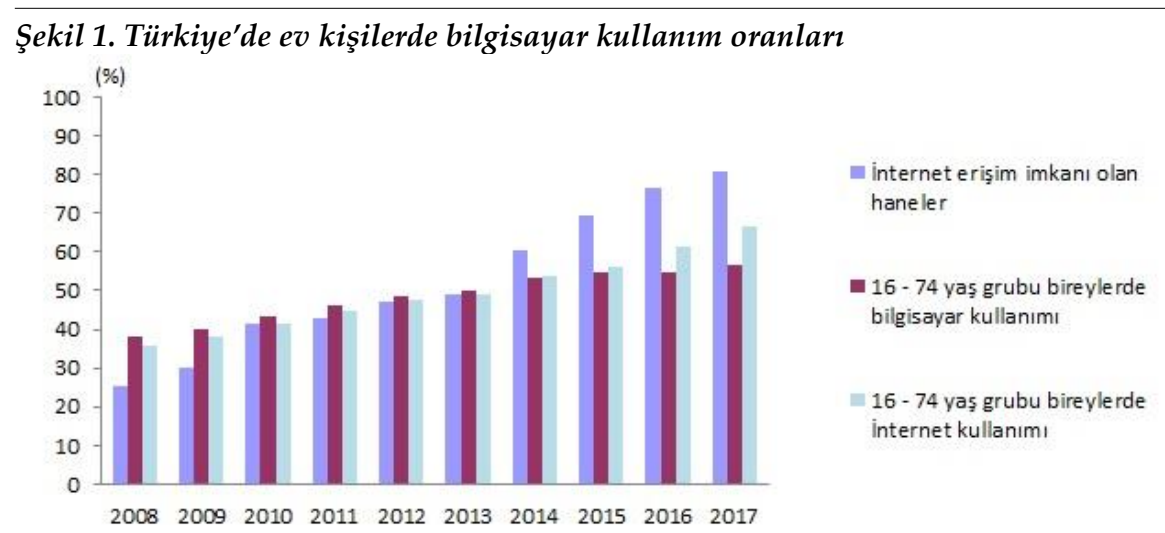

Kaynak: http://www.tuik.gov.tr/PreHaberBultenleri.do?id=24862

Z kuşağının beslenme konusunda daha tutarlı bir davranış sergiliyor.. $Y$ kuşağı diyet yapma, zayıflama, formda ama gibi endişeler taşırken, $\mathrm{Z} \mathrm{ku-}$ şağı bireyleri beslenme alışkınlarını hayat tarzı olarak benimsiyorlar ve kendilerini olduğu gibi kabul ediyorlar. Bu jenerasyonun doğaya, tabiat varlıklarına olan ilgileri yüksek seviyede, Z kuşağına ait 10 bireyden 7'si, doğayı önemsiyor, çalışmaları benimsiyor ve sahip çıkmaya çalışıyor. (www.hurriyet.com.tr)

Bütün bu özeliklerine istinaden $\mathrm{Z}$ kuşağının veya jenerasyonunun olumlu ve olumsuz yönlerini şöylece sıralayabiliriz.

\section{Z kuşağının olumlu yönleri}

- Ne istediklerini biliyorlar.

- Bireysel ve bağımsız çalışmak özelliği taşıyorlar.

- Dürüstler.

- Hiçbir Kompleksse girmeden kendilerini rahat ifade edebiliyorlar.

- Girişimcilik yönleri ve istekleri fazla

- Farklılığın kutlandığı ve benimsendiği renkli bir iş hayatı ve daha az hiyerarşi talep ediyorlar.

\section{Z kuşağının olumsuz yönleri}

- Sadakatsizlik ve kolay vazgeçmeleri şirketler için sorun olabilir.

- Ben merkezli olmaları takım çalışması gerektiren işlerde sorun yaşanmasına neden olabilir. 
- Sürekli yükselme beklentisi içinde olmalar rekabeti daha da sertleştirebilir.

- Yenilikçi ve eğlenceli işler yapma beklentisi içinde olmalar standart işleri yaptırmay zorlaştırabilir.

- Aceleci ve sabırsı olmaları zaman ve emek gerektiren meslek dallarına değer kaybettirebilir(www.turkishtimedergi.com).

\section{Z Kuşağı ve İş Hayatı}

Z kuşağı, 1990'lı yılların sonlarında doğan başka bir ifadeyle İGen olarak sinıflandırılan bu nesil çoğunlukla stajyer olarak da olsa şimdilerde iş hayatına girmeye başladı. Türkiye' de Z kuşağı olarak ifade edebileceğimiz bireylerin sayısı 18 milyon civarında. Dolayısıyla bizimki gibi genç nesil oranının bu denli yüksek olduğu bir ülkede $Z$ kuşağını anlamak ve onlara hitap edebilmek kritik önem taşıyor. Bugüne kadar yapılan araştırmalar bu neslin sabırsız, sadakatsiz ve kolay iletişim kuramadığı şeklinde bir sonuç ortaya koyuyor. Araştırma sonuçları ne olursa olsun örgütlerin, geleceğin çalışanları ve müşterileri olacak bu neslin hayallerini ve beklentilerini anlayabilmeleri gerekiyor. Bunun için de öncelikle bu olumsuz algının kökenlerine inmek gerekiyor.

Fransa da BNP Paribas ve The Boson Project (group.bnpparibas) tarafından, 15 - 20 yaş arasındaki 3.200 Fransız gençle yapılan anket, Z kuşağının çalışma hayatına ve şirket ortamına çok farklı bakış açısı olduğunu gösteriyor. Bu çalışma her ne kadar sadece Fransız gençleriyle yapılmış olsa da, küreselleşmenin ve yeni teknolojilerin birbirine çok yaklaştırdığ 1 dünya gençliği hakkında da iyi bir fikir veriyor. Bu ankette ortaya çıkan sonuçlar; gençlerin, şirketten ve şirkette çalışma hayatından söz ederken 'çok zor', 'çok karışık', 'sıkıcı', 'acımasız', 'vahşi orman' algıları ön planda ve 100 gençten 36'sı için şirket demek 'stres' demek diyor. Z'ler, sürekli bağlı, iletişim ve etkileşim halinde oldukları bir eko-sistemin yörüngesinde yaşadıkları için, bu gençlerin yaklaşık yüzde $40^{\prime}$ ı başarıyı iyi bir network ile mümkün görüyorlar. $Z$ kuşağı her şeyin (cep telefonu modelleri yahut internet oyunlarının versiyonları gibi) hızla eskidiği bir dünyada doğup büyüdükleri için, bilginin de çabuk eskiyeceği düşüncesindeler, dolayısıyla bilgilerini ve kendilerini ‘sürekli güncellemeleri' gerekeceğine inaniyorlar. 
Çalışma hayatında, bir işte ya da bir sektör de devamlı kalmak istemiyor. Gençlerin \% 38'i "İş hayatı sürecinde en az beş meslek değiştirmek eğiliminde olduğunu \% 84,5'i heyecan duyacakları bir iş yapacağını söylüyor. (www.hurriyet.com.tr) Hızlı teknoloji ve kolay bilginin gölgesinde yetişen bu neslin her işinde aceleci davraniyor. Her şeyi, her yerde ve şimdi istiyorlar. Onlar zihinlerinde merak ettikleri her şeyi saniyeler içerisinde indirmeye ve kullanmaya alışmışlar. Y kuşağına kıyasla sabırlı davranmayı öğrenmeleri daha uzun sürecek. Değişime olan iştahları nedeniyle "Ben" odaklı yaşayan bu neslin sadakat duygusunun düşük olduğu konusunda herkes fikir birliği içerisinde. Bu neslin sabırsız olup her şeyden çabuk sıkılmaları onları elde tutabilmeyi daha da zorlaştırıyor.

Eski nesillere kıyasla her istediklerini çok daha kolay elde ettikleri için sahip olduklarına değer de vermiyorlar. Bu nesil işiyle özel hayatı arasındaki dengeye $Y$ kuşağından çok daha fazla değer veriyor, yeni nesil çok yoğun çalışma ortamında bile eğlenmekten vazgeçmek istemiyor. Z kuşağının olumsuz gibi algılanan bu özellikleri sağlıklı biçimde yaklaşıldığında iş ortamına pozitif anlamda katkı sağlayabilir. Bu değişimin iş hayatına olumlu yansıması için uzmanların tavsiyesi, daha eğlenceli ve risk almaya açık bir ortam oluşturmak. Birçok sektör yöneticisi Z'lerin iş dünyasında artması ile iş ortamlarında daha çok ekranın olacağını, kâğıdın, prosedürlerin iyice azalıp, esnek çalışma saat ve modellerinin yoğunlaştığı, pek çok yeni görevin ortaya çıtı̆̆ı, film setlerine benzer ortamlara dönüşeceğini "Bölümlerin yerini proje grupları, geçici ekipler, uluslararası takım üyeleri alacak ,farklı kültür, cinsiyet, inanç taşıyan rengarenk insanlar, kadın-erkek eşitliğine doğru giden bir ivmede çalışmaya başlayacağını belirtiyorlar.

Dünyanın önde gelen firmaları bu anlayışla harekete geçerek ofis ortamlarını bu bakış açısı çerçevesinde yeniden dizayn etmeye başlıyorlar. Çalışanlarının, sosyalleşebilecekleri ve ofis içinde bile rahat hissedebilecekleri ortamlar da, eğlenceli aktiviteler düzenlemeye çalışıyorlar. Böylece bireysel düşünmeye alışan bu neslin takım çalışmasına adapte olabilmesi için de faydalı bir adım atılmış oluyor. Hiyerarşiye eski kuşaklara kıyasla daha mesafeli durmaları da demokratik yönetim biçimlerinin yükselmesini beraberinde getiriyor. Farklılığın bastırılmadığı aksine kutlandığı renkli bir iş hayatı ortaya çıkacak. Böylece iyi ve kreatif fikirler de hiyerarşik düzenin içerisinde kaybolup gitmemiş olacak (nextgenclub.net). 


\section{İş Dünyasının En Yenileri: Z kuşağı ve İş Hayatına Muhtemel Etkileri}

Günümüzde her alanda yaşanan değişimler toplumsal, kültürel, hukuk, eğitim ve teknoloji alanlarda hayatımızı etkilemektedir. Bu değişimler toplum yapısını da, toplumu oluşturan insanların değer yargılarını, beklentilerini, inançlarını da etkileyerek değişmelerine sebep olmaktadır. Kuşaklar arası geçişler günümüzde her zamankinden daha mümkün görülmektedir. Geçmişteki azla yetinen, otoriteyi sorgusuz kabul eden çalışanların yerine daha bilgili, azla yetinmeyen, gerektiğinde sorgulayan, beklentileri ve ihtiyaçları farklı kendine zaman ayırmayı önemli bulan yeni nesil bir iş gücü gelmektedir (Sadullah, 2010: 7).

2016'da Mc Kinsey tarafından yapılan bir araştırmada, bugün insanların karşlığında ücret alarak yaptığı işlerin \%45'i teknolojinin gelişmesiyle bilgisayar destekli makineler tarafından otomatik olarak yapılabileceğini ortaya çıkardı. Bu sonuçlar gelecekte işsizliği artıracağı kanısını uyandırıyor, ancak durum pekte öyle değil. Çünkü istihdam piyasasında daha önce de bu tür şartlar oluştuğu görülmüştür. Örneğin daktilocular yerini sözcük işlemci programlarına, veznedarlar müşteri temsilcilerine bırakmış durumda. İş imkânlarının değişmesi, dönüşmesi, bozulması veya yeniden şekillenmesindeki tek fark ihtiyaç duyulan iş becerilerinin değişme hızının en yüksek seviyede olması ve bu değişimin baş döndüren bir hızla gerçekleşmesi. Dijitalleşme çağında, belki de henüz adı bile duyulmamış işlerde kalıcı olmak için hızla yeni beceriler edinmek ve bu becerileri daha sık kullanmak gerekecek.

$Z$ kuşağının çalışacağ iş̧lerin yüzde 65'i, şu anda dünyada var olmayan işler. Dünyada var olmayan bir iş konusunda eğitim planlaması yapılamaz, ancak kişilerin yeteneklerini ve öğrenme becerilerini geliştirmek yönünde bir eğitim planlanabilir.

ManpowerGroup tarafından yapılan ve 43 ülkeden 18.000 işverenin katıldığ1 Yetenek Devrimi (The Skills Revolution) araştırması, istihdam açısından gençleri parlak bir geleceğin beklediğini ortaya koydu. Araştırmaya göre, her beş işverenden biri (\%19), geleceğin iş dünyasına adapte olunabildiği takdirde teknolojik gelişmelerin iş imkânlarını artıracağını, her 10 işverenden altısı (\%64) ise çalışan adaylarının istenilen becerilere sahip, öğrenmeye, uygulamaya ve adaptasyona hazır olması halinde çalışan sayısını artıracağını, en azından aynı tutacağını belirtiyor. İşverenlerin 


\section{\%90'dan fazlası ise önümüzdeki iki yıl içinde işletmelerinin dijitalleşme trendinden etkileneceği yönünde düşünceye sahipler www.btnet.com.tr).}

Tablo 2 : X, Y Ve Z Kuşağının İş İle İlgili Özellikleri Ve Düşünceleri

\begin{tabular}{|c|c|c|c|}
\hline İş Özelliği & X Kuşağ1 & Y Kuşağı & Z Kuşağ1 \\
\hline İş Etiği & Dengeli & Hevesli & Daha gerçekçi \\
\hline $\begin{array}{l}\text { İş Hakkındaki } \\
\text { Görüş }\end{array}$ & $\begin{array}{l}\text { İş, bir meydan } \\
\text { okumadır. }\end{array}$ & $\begin{array}{l}\text { İş, farklılık yaratmak } \\
\text { için yapılır. }\end{array}$ & $\begin{array}{l}\text { İş, heves ve enerji } \\
\text { ile yapılır. }\end{array}$ \\
\hline $\begin{array}{l}\text { Kişisel Özellik- } \\
\text { ler }\end{array}$ & $\begin{array}{l}\text { Pratik, esnek, bireyselci, } \\
\text { girişimci, yaşam } \\
\text { kalitesi ile ilgili }\end{array}$ & $\begin{array}{l}\text { Siyasal bilince sahip, } \\
\text { yüksek beklentili, } \\
\text { takım kurucu, } \\
\text { farklılıklara karşı } \\
\text { anlayışlı, kendine } \\
\text { güvenen, meydan } \\
\text { okumalara açık }\end{array}$ & $\begin{array}{l}\text { Teknoloji meraklısı, } \\
\text { erken olgunlaşan, } \\
\text { şımartılmış, } \\
\text { güçlendirilmiş, risk } \\
\text { karşıtı, korunan }\end{array}$ \\
\hline $\begin{array}{l}\text { İş ile İlgili } \\
\text { Özellikler }\end{array}$ & $\begin{array}{l}\text {-İşyeri politikalarını } \\
\text { sevmeme } \\
\text { - İşgörene çok bağlı } \\
\text { olmama } \\
\text { - Birden çok görevi } \\
\text { aynı anda yapabilme } \\
\text {-Eşit oranda } \\
\text { sorumluluğa sahip olunan } \\
\text { iş ortamını sevme } \\
\text {-Proje yapmayı sevme } \\
\text {-İş unvanlarından çok } \\
\text { iş sorumluluklarına } \\
\text { önem verme } \\
\text {-Performansı çıktıya } \\
\text { göre değerlendirme } \\
\text {-Güç yapılarını } \\
\text { sevmeme } \\
\text {-Otoriteye karşı esnek } \\
\text { olma } \\
\text {-Serbest kıyafetin rahat } \\
\text { olduğunu düşünme }\end{array}$ & $\begin{array}{l}\text {-Nedenleri bilmek } \\
\text { isteme } \\
\text {-Herkesin önünde } \\
\text { övülmek isteme } \\
\text {-Eğlenceli bir } \\
\text { işyerinden hoşlanma } \\
\text {-Paranın güdüleyici } \\
\text { olmadığını düşünme } \\
\text {-Anlık sorumluluk } \\
\text { isteme } \\
\text {-Zaman sınırlı küçük } \\
\text { hedefler isteme } \\
\text {-İş-yaşam dengesinin } \\
\text { önemli olduğunu } \\
\text { düşünme } \\
\text {-Bir işletme ile uzun } \\
\text { ömürlü bir ilişki iste- } \\
\text { meme } \\
\text {-Yeteneklerine } \\
\text { güvenme }\end{array}$ & $\begin{array}{l}\text {-Yaratıcı ve } \\
\text { işbirlikçi olma } \\
\text {-Oldukça zor } \\
\text { çevresel, sosyal ve } \\
\text { ekonomik sorunları } \\
\text { çözmek zorunda } \\
\text { kalma } \\
\text {-Kendi kendini } \\
\text { yönlendirebilme } \\
\text {-Bilgiyi çok hızlı } \\
\text { işleyebilme } \\
\text {-Daha zeki olma }\end{array}$ \\
\hline
\end{tabular}

Kaynak: Çetin, C. E Karalar, S. (2016), X, Y ve Z Kuşă̆ı Öğrencilerin Çok Yönlü ve Sınırsız Kariyer Algıları Üzerine Bir Araştırma, 
Birkaç yıla kadar üniversitelerden mezun olup çalışma hayatına atılacak olan ve diğer kuşaklardan farklı beklentilere ve öğrenme biçimlerine sahip olan bu yeni kuşak, dijital süreçlere de son derece hâkim olmalarıyla şirketleri dönüştürecek, iş hayatının dinamiklerini değiştirecek bir jenerasyon. İnsan Kaynakları departmanlarının kazançlı çıkacağını vurgulayan insan kaynakları uzmanları, Z kuşağının beklentilerini şeffaflık, fırsat eşitliği, kendini özgürce ifade edebildiği ve hiyerarşiden uzak bir iş yeri olarak tanımlıyor. Z kuşağının detaylarda boğulmama, sonuca odaklanma ve kompakt düşünme yeteneklerinin iş hayatında yararlı olacağını vurguluyorlar.( www.kariyer.net)

\section{Z kuşağının iş dünyasından beklentileri}

- İş yerinde ve çalışma zamanında esneklik

- İş -yaşam dengesi

- Hiyerarşik yapıdan çok organik örgütlenme,

- Hem dikey hem yatay kariyer ilerlemesi olanağı,

- Verilen işlerde monotonluktan uzak, yenilikçi ve teknolojinin entegre edildiği görevler,

- Başarısının, çalıştı̆̆ 1 saatten çok yaptığı ve ortaya çıkardığı iş ile değerlenmesi

- Maddi tatmin kadar manevi tatmin de sağlayan fırsatlar ve getiriler,

- Takım ruhundan daha çok bireysel çalışmayı tercih ettikleri için bireysel ofisler

- Teknolojik araçlar (Bilgisayar, internet vb.) kendilerine tahsis edilmesi(Arar, 2016)

$\mathrm{Z}$ kuşağının iş hayatındaki yönetici ve patronlardan diğer bir beklentisi "Yetenek Yönetimi" dir. Çalışanları tanıma, onları yönetme ve geliştirme yoluyla şirketin geleceğini inşa etme süreci "Yetenek yönetimi" olarak tanımlanır. İnsan kaynakları gündeminde yer alan önemli bir kavramdır. Yetenek yönetiminde başarılı olmak için yeteneği tanımlamak ilk ve en önemli adımdır. İşte bu noktada kuşakların değişimi işleri zorlaştırır. Bu durumda okullar ve aileler bu kuşağa ne kadar hazır? iş dünyası Z kuşa$\breve{g} ı n ı$ karşılayacak donanımlara sahip mi? Yetenek yönetimi stratejileri geleceği inşa etmeyi amaçladığına göre bu sorunun şimdiden cevaplanmış 
olması beklenir. Ancak Y kuşağının yaşadığı uyum problemleri bu işe pek de hazır olmadığımızı ortaya koyuyor.

Z kuşağının otoriteye yaklaşımı çalışma ortamına uyum derecesini etkileyecek en önemli farklardan biridir. Otorite sahibinin kendisini birey olarak tanımasını ve ona göre yaklaşmasını bekler. Yetenek yönetimi içerisinde ödül, prim ve terfiler şeffaflaşırken şirket içi iletişim yatay hale gelir. Böylece alt kademelerin dinamizmi artarken, $Z$ kuşağının bağımsız duruşu iş kararlarının etkinliği artırabilir. $Z$ kuşağının otoriteye bakış ve iletişim tarzının doğru anlaşılması süreci kolaylaştırır. Şirket kültürü hiyerarşisinden sıyrılıp açık işbirliğine geçebilen şirketler $Z$ kuşağ 1 için çekici hale gelebilir.( www.analizkariyer.com)

\section{SONUÇ}

Teknoloji, Z kuşağını şekillendirdiği kadar iş dünyasını da şekillendiriyor. Firmaların esnek çalışma modellerine geçmelerinin en önemli sebeplerinden biri de firmaların bu durumdan tasarruf sağlayarak kârlı çıkması.

Z kuşağının çeşitli kişilik özelliklerinin oluşmasında ailelerinin genellikle $X$ kuşağı kişilerinden meydana gelmesi önemli bir faktördür. $X$ kuşağı bireyleri pek çok zorluklarla mücadele etmiş ve çocuklarının yaşama karşı dik durmalarını sağlayabilmek için kendi kararlarını vermeyi öğrenmelerini, eğitim almalarını, meslek sahibi olmalarını sağlamışlardır. Z kuşağı bireylerinin, ebeveynleri ile olan tutumları ve ilişkileri oldukça kuvvetlidir. Bu nedenle $\mathrm{Z}$ kuşağ ${ }_{1}$ bireylerinin genellikle iş planlamalarında ailelerinin de etkili olduğu gözlenmiştir. Esnek çalışma saatleri ile çalıştıkları ortamın rahat olmasını istemekte ve bu nedenle de Z kuşağı bireylerinin çoğunluğu girişimci olmak istemektedir.

$\mathrm{Z}$ kuşağ 1 bireyleri, kendilerine oldukça güven duyarlar ve bu nedenle iş yaşamlarında farklı sorumluluklar almayı isterler. Bu kişiler, iletişim ile yönetim, değişik fikirler, hızlı bilgilenme gibi pek çok konularda başarılı olabilecekleri beklenmektedir. Z kuşağı bireylerinin çalışma ortamlarının modern ve teknolojik biçimde tasarlanmış olması, bu ortamda donanımlı araç ve gereçlerin bulunması daha verimli çalışmalarına ve aktif performans göstermelerine fayda sağlayacaktır. Yapılan araştırmalar, grup çalışmasının Z kuşağının verimliliğini düşüreceğini, kişisel çalışma imkânı ile daha başarılı olacağını göstermektedir. 
Z kuşağı, hoşgörüyle yaklaşıldığında, bulunduğu ortamlara artı değer katabilir, iş hayatının ve toplumun dinamiklerini olumlu yönde değiştirebilir, Özellikle eğitimcilerin ve yöneticilerin, diğer kişilerle bu kuşağın uyumlu çalışması yönünde stratejiler geliştirmesi gerekir. Yöneticiler, İşletme politikalarını, bu kuşağın yenilikçi bakış açısı ve analitik zekâlarına paralel olarak geliştirilebilir. Bu gelişme hem işletmenin hem de $\mathrm{Z}$ kuşağ bireylerinin iş hayatındaki yükselişi için önem arz etmektedir. İşletmedeki tecrübeli kuşak ile yeni kuşak arasındaki dengenin sağlanması, çalışma şartlarının bireylerin durumlarına göre düzenlenmesi fark oluşturacaktır.

Bu bağlamda; "İşs süreçleri mutlaka teknoloji ile desteklenmiş ve bürokrasiden uzak tasarlanmış olacağı için “Ben” odağı yükselen çalışanların bireyselleşen taleplerine karşılık verecek esnek sistemler tanımlanması ve ortamlar oluşturulması gerekecektir. Standart politikaları bir kenara b1rakmak zorunda kalacak olan insan kaynakları bölümlerinin ise hızlı ve esnek olmalarını sağlayacak yeni politikalara ihtiyaçları olacaktır.

\section{KAYNAKLAR}

Altuntuğ N., (2012). Kuşaktan kuşağa tüketim olgusu ve geleceğin tüketici profili. Organizasyon Ve Yönetim Bilimleri Dergisi, 4(1), 203-212

Arar,T., (2016), Z kuşağında kariyer geliştirmede yetenek yönetimi. Yüksek Lisans Tezi, 104-105

Comte, Auguste, (1974). The positive philosophy (New York: AMS Pres.) (Ed.: Abraham S. Blumberg).

Çetin, C. Karalar, S. (2016). X, Y ve Z kuşağı öğrencilerin çok yönlü ve sinırsız kariyer algıları üzerine bir araştırma. Yönetim Bilimleri Dergisi, 14(28), 157-197.

Hammill, G. (2005). Mixing and managing four generations of employees. FD Magazine Online, 12(2). fdu.edu/newspubs/magazine/05ws/generations.htm.

Howe, N. ve W. Strauss. (1992). Generations: The History of America's Future, 1584 to 2069, Quill Publications.

Lagree, Jean Claude (1991), Générations!. Les Annales de Vaucresson ‘dan, Latif, H., Serbest, S.,( 2014)Türkiye’de 2000 Kuşağı ve 2000 
Kuşağının İş ve Çalışma Anlayışı, Hasan Latif- Salih Serbest, Gençlik Araştırmaları Dergisi 2(4), 136

Latif, H., Serbest, S.,( 2014). Türkiye'de 2000 kuşağı ve 2000 kuşağının iş ve çalışma anlayışı.Gençlik Araştırmaları Dergisi 2(4), 136

Mannheim, Karl (1998). Collected Works of Karl Mannheim, 5, New York: Routledge

Mitchell, D.A., (2008). Generation Z: Striking the balance: healthy doctors for a healthy communit, Australian Family Physician, 37, 8, 665-672.

Ross, S., (2013). How definitions of talent suppress talent management. Industrial and Commercial Training, 45, 3, ss. 166-170

Sadullah, Ömer (2010), İnsan kaynakları yönetimi. İstanbul: Beta Basım. Senbir, H. (2004). Z son insan mı?. İstanbul: Okuyan Us Yayınları.

Williams, S. (2010). Welcome to generation Z. BET Magazine. 60, 2731. www.tdkterim.gov.tr

www.milliyet.com.tr/z-kusagi--genclerin-dinamiklerini-pembenar-detay-cocuk-1864431/

www.fortuneturkey.com/mobil-yakalilar-42504

www.analizkariyer.com/MakaleDetay.aspx?HaberID=ab914a20-4d9a4b16-8b50-b197be7cefad

indigodergisi.com/2017/02/z-kusagi-calisma-onceligi/

www.kariyer.net/ik-blog/is-dunyasinin-en-yenileri-z-kusagi/은

www.btnet.com.tr/z-kusagi-yepyeni-islerde-calisacak/

www.sabah.com.tr/iste-insan/2017/04/09/teknolojik-gelismeler-isimknini-artiracak

nextgenclub.net/next-ceo-yaziyor/is-hayatinda-y-kusagindan-z-kusagina-gecis/

www.hurriyet.com.tr/sirketler-z-kusagi-kapinizda-29575932 group.bnpparibas/communique-de-presse/bnp-paribas-boson-projectpublient-premiere-etude-generation-grande-invazion www.turkishtimedergi.com/insan-kaynaklari/ve-z-kusagi-is-hayatinaadimini-atiyor/

www.hurriyet.com.tr/yazarlar/idil-tatari/y-bitti-sira-zde-40463834

www.hurriyet.com.tr/sporarena/z-kusagina-dair-ilginc-bir-arastirma$\underline{40631945}$

epnext.com/e-ticareti-z-kusagi-ucuracak/

ikiletisim.wordpress.com/2014/09/03/z-kusagi-gumbur-gumbur-geliyor/ 
www.humanica.com.tr/kusaklari-anlamak-yonetmek/ ikiletisim.wordpress.com/tag/y-kusagi/ www.hurriyet.com.tr/yazarlar/23465715.asp danisman-muratdanisman.blogspot.com/2012/06/x-y-z-kusaklar.html www.hurriyet.com.tr/yazarlar/23465715.asp www.mostar.com.tr/koseDetaylar.aspx?id=1298 www.humanica.com.tr/kusaklari-anlamak-yonetmek/ www.tuik.gov.tr. www.dijitalajanslar.com

\section{Kaynakça Bilgisi / Citation Information}

Taş, H. Y., Demirdöğmez, M. ve Küçükoğlu, M. (2017). Geleceğimiz olan z kuşağının çalışma hayatına muhtemel etkileri. OPUSUluslararası Toplum Araştırmaları Dergisi, 7(13), 1031-1048. 